\title{
Bourdieu's Field Theory and Science Education: Possible Articulations and Appropriations
}

\author{
Luciana Massi, ${ }^{(1)}$ Gabriela Agostini, ${ }^{(1)}$ Matheus Monteiro Nascimento
}

Keywords Abstract Based on contributions from the sociology of science Sociology of in the field of Science Education, this article aims to explore and

Science; elucidate the concept of fields, formulated by Pierre Bourdieu, in the

Bordieuan field; objects of study of this area. This theoretical study is structured in Science Education. three parts, which are articulated throughout the text: a synthesis of the general and invariable principles of fields; an elaboration of an analogy between the different field theories (sociology and physics); a discussion about the appropriation of field theories in research studies on Science Education that use them. We discuss the field as a social space, the agents' habitus, the positions in the field, disputes and interests, distribution of the specific capital, limits, boundaries, and the field autonomy. An interpretation of this complex Bourdieusian concept was defended, in a way to determine the limits of the field and their agents, based on how research has appropriated it. Therefore, a theoretical framework was advanced, coming up with the possible and effective articulations between Science Education and Bourdieu' Sociology of Science.

\section{Introduction}

Research in Science Education represents an amalgamation between different fields of human and exact sciences. At this junction, contributions from psychology and pedagogy are fundamental for understanding the processes of teaching and learning science. This initial and central object of study has been expanded significantly through fundamental contributions from history and philosophy of science, language sciences and socio-cultural theories. Despite this, sociology still seems to be little explored for its direct contribution to educational issues, at the same time that, as Valadão (2016) also observed, the ideas of some sociologists of science have been investigated. In this article, we propose to explore the potential of the concept of fields, formulated by Pierre Bourdieu and pivotal in his sociology of science, to broaden our perceptions about some objects of study in our area. 
The concept has been investigated by some authors in a very creative and diverse way, evidently concerned with schools, non-formal spaces and science as a field (Feres, 2010; Genovese, 2013; Watanabe et al., 2013). The concept of fields was elaborated by Bourdieu as an instrument of thought capable of indicating a direction to researching and that can be applied in different domains. The idea of field arises as an alternative to the simplistic and illusory view of internal interpretation versus external explanation. Against the reductionism that directly relates a cultural form to a social form, Bourdieu (1989a) valued the relational way of thinking, which is of central importance to his theory. Furthermore, the concept has the power to put science at the service of scientific progress and to take prescriptive positions (Bourdieu, 2004a).

Engrossed in several cases, each with their own particularities, and guided by the primacy of empiricism, the sociologist built the concept of field while applying it in different domains: in haute couture (Bourdieu, 2002a), art (Bourdieu, 1996), science (Bourdieu, 1983a , 2004a, 2004b), economy (Bourdieu, 2005), politics (Bourdieu, 1989b), religion (Bourdieu, 2007a), sports (Bourdieu, 2004c), law (Bourdieu, 1989c), language (Bourdieu, 2008), in the intellectual (Bourdieu, 2004d) and academic (Bourdieu, 2017) environments, among others.

His theory of fields emerged "from generalization to generalization", with each empirical study from distinct universes revealing both specific properties and the recurrence of common and invariant properties, which acted as universal mechanisms or general laws of fields (Bourdieu, 1989a, p .69). Consistent with general sociological, relational and dialectical theories, the concept of field relies on and grows out of other central concepts in Bourdieusian sociology such as habitus, capital, strategy, structure, etc. All of these elements contribute to the difficulty of understanding and mobilizing the concept, explicitly highlighted by Bourdieu (2013), Lahire (2017) and Montagner \& Montagner (2010). For Grenfell (2018), the adoption of the concept of field should be present in all research studies involved with Bourdieu's ideas, presenting a deeper application of the Bourdieusian theory and representing a higher level of understanding compared to the adoption of isolated concepts, such as habitus and capital. Therefore, this concept with so many potentialities for the sociology of science, which has been used to investigate important objects of study for Science Education, requires greater clarity and depth that is easily found in the literature.

Therefore, in this article, we systematize the results of a detailed reading of the author's works on fields, as well as a selection of texts on Science Education (Valadão, 2016) that mobilized his theories, so that we can contribute to the understanding and dissemination of the concept in the area, explaining possible and present articulations. Thus, we aim to make the concept of field theoretically clearer, illustrating how it has been appropriated on Science Education and an analogy with the concept of field present in Physics. In other words, our main objective is to deepen the understanding of this difficult concept through an analysis of appropriations in works on Science Education and an analogy. This is a theoretical and conceptual study that did not intend 
to completely revise the literature, to deepen the discussions on analogy, nor to exhaust the possibilities of appropriation of the concept of field in the area. We emphasize that the similarities presented between the social and the physical world will at times be mere appearance or literal; in other cases, however, they will be analogies themselves (Genter, 1983). We understand the relevance of recognizing these differences (Mozzer \& Justi, 2013), however, in the present work we will synthetically use analogy as a noun that denotes similarities and conformities, and not in the strict sense of the concept widely discussed in the area of Science Education.

In order to produce this theoretical analysis, for a year we have carefully read several works by Bourdieu on the general concept of field (1983c, 1989a), on other fields (1983b, 1989b, 1989c, 1996, 2002a, 2004c, 2004d, 2005, 2007a, 2008) and on the scientific field (1983a, 2004a, 2004b, 2017), producing syntheses on general and invariable laws and the specific properties of fields. This is a first draft of a comparison between the concept of field for Bourdieu and for Physics, which served as the basis for the analogy presented here.

Then, we resume Valadão's (2016) bibliographic review of the appropriation of the Bourdieusian framework in research in Science Education. The author performed a systematic review of the main publications in the area: in the annals of the 1st to the 9th National Research Meeting in Science Education (ENPEC); in journals of Education rated A1/A2 (Brazilian Journal of Physics Teaching, Brazilian Journal of Research in Science Education, Science \& Education, Ensaio - Research in Science Education and the journal Investigations in Science Education); in theses and dissertations available at the Science Teaching Documentation Center and at the CAPES Bank of Theses and Dissertations. From the total of 160 works analyzed by Valadão (2016), we selected 16 that mobilized the concept of field (Braga, 2004; Conceição, 2012; Condenanza \& Cordero, 2011; Dorvillé, 2010; Feres, 2010; Feres \& Nardi, 2007; Freitas, 2008; Freitas, Oliveira \& Carvalho, 2005; Freire \& Fernandez, 2015; Genovese, 2013; Martins, Gouvea, Jansen \& Terreri, 2005; Pereira, 1999; Perrelli, 1996; Perrelli \& Gianotto, 2005; Ribeiro, 2008; Watanabe et al., 2013). Based on these references, we tried, when possible, to substitute annals for theses and dissertations by the same authors, looking for broader approaches to the concept of fields, thus including the theses of Condenanza (2012), Genovese (2008) and Watanabe (2015), totaling 19 texts. In view of the complete reading of these materials and considering the objects of study of the authors, we analyzed how the concept was being mobilized, which properties of this concept and what other Bourdieusian concepts were articulated, what was the theoretical panorama in which Bourdieu was inserted in these studies and what were the advances and limitations of these theoretical efforts. We emphasize that some works were not included in our analysis, especially those published after 2015, since we based only on the review by Valadão (2016). In this sense, we do not intend to make generalizations, but to present a broad, time-situated picture of the appropriation of the concept of fields in research studies on Science Education. 
In a general and descriptive way, we initially highlighted the prevalence of ten theses and dissertations (Braga, 2004; Conceição, 2012; Condenanza, 2012; Dorvillé, 2010; Feres, 2010; Freitas, 2008; Genovese, 2008; Perelli, 1996; Ribeiro, 2008; Watanabe, 2015), a single article (Freire \& Fernandez, 2015) and eight annals (Condenanza \& Cordero, 2011; Feres \& Nardi, 2007; Freitas, Oliveira \& Carvalho, 2005; Genovese, 2013; Martins et al., 2005; Pereira, 1999; Perelli \& Gianotto, 2005; Watanabe et al., 2013), five of which (Condenanza \& Cordero, 2011; Feres \& Nardi, 2007; Genovese, 2013; Perelli \& Gianotto, 2005; Watanabe et al. 2013) were directly related to the theses and dissertations of the same authors. These are studies based exclusively on qualitative data collection methods, with emphasis on interview techniques and analyses of the subjects' discourses. In this sense, some works used Laurence Bardin's Content Analysis as a technique of data selection, organization and analysis. We also noticed that, in most works, the Bourdieusian theoretical framework was accompanied by other authors, such as Paulo Freire, Thomas Kuhn, Ives Chevallard, among others. For example, Freitas (2008) indicated that Bourdieu did not provide for analysis at the epistemological level of the study, which is why Paulo Freire was used. Finally, although it is a small group of 23 authors, we highlight the absence of citations among this group of authors, that is, we noticed that the authors in Science Education did not mention their colleagues who also adopted the Bourdieusian concept of field and eventually did not even cite their own research published in another context.

This paper is structured in such a way that, throughout the whole text, we present the concept of field from Bourdieu, deepen this concept through an analogy with Physics and discuss how the concept of field was appropriated by studies in Science Education.

\section{Field as a social space}

Bourdieu builds the concept of field in direct association with the physical notion of space. For the author, fields are like microcosms within the social macrocosm. In other words, the concept of field is precisely related to the notion of space, more precisely of social space. The philosopher Nikolaus Fogle (2011) clearly demarcated the relationship between field and space in the Bourdieusian work. In the author's words:

The conception of the religious field that Bourdieu constructs in response to Weber exemplifies what he calls a field of cultural production: a field whose content is restricted to a particular type of cultural activity, such as literature, painting, journalism or law, and which is understood to be a sub-space of the more encompassing social space. (Fogle, 2011, p. 4).

Thus, when Bourdieu referred to literary, artistic, academic or religious fields, these are all subspaces surrounded by a large social space. In these subspaces of social space, which are generically called fields, agents (individuals, institutions, etc.) are positioned as if they were charged particles located somewhere in the physical space. Like particles, these agents interact with each other in this space, and the consequences 
of these interactions are closely related to these agents' intrinsic properties.

But what space are we talking about? The modern physical notion of space is the result of a long and continuous process of abstraction that traces back to the origins of the human being (Jammer, 1993). Moving away from purely geometric descriptions, Newton conceives space as an absolute reality, in which physical phenomena can be described mathematically (dos Reis \& Reis, 2016; Porto \& Porto, 2008). Therefore, space would only be a passive territory of events, without any influence or interaction with physical phenomena. Over time, Newton's proposition about absolute space gradually consolidated among those who thought about the physical world (Jammer, 1993; Porto \& Porto, 2008). Despite the success of Newtonian mechanics, his ideas about the absolutism of space were nevertheless questioned by thinkers like Gottfried Leibniz, Leonhard Euler, Ernest Mach and Henri Poincaré (Porto \& Porto, 2008). In addition to these criticisms, the problem of incompatibility between Maxwell's electromagnetic theory and Newton's laws of motion gave rise to a new physical interpretation of space and time: the theory of special relativity proposed by Einstein (Jammer, 1993). For this, the contributions of the mathematician Riemann were fundamental, as he assumed space as an active agent of physical events (Einstein, 2011). In short, after Einstein, the idea of an absolute space was replaced by a connection with time in a continuum of four inseparable dimensions.

Thus, the social space investigated by Bourdieu is anchored in this modern notion of physical space, in which the spatial dimensions are intertwined with the temporal dimension. In his work, Bourdieu uses a flat two-dimensional representation of social space. Although time is considered in Bourdieusian analyzes, it is not represented, as it is in a dimension perpendicular to the social space (Fogle, 2011).

This notion of field as a space or subspace within the social space is present in the analyzed literature on Science Education. As an example, in the thesis by Freitas (2008), the concept of field is mobilized to understand the relations between the work of the university teacher and the school teacher. The author "seeks to place the academic person, in the form of a university professor, as an integral part of an autonomous social structure that relates to other structures in the 'social space"' (Freitas, 2008, p. 15). For Freitas (2008), this autonomous social structure located within a larger social space is exactly what is meant by field, which corresponds to the academic or university field in this case. The article concludes by recognizing the differences between the social space occupied by these two agents and advocating the creation of "inter-field" spaces that enable communication and exchange knowledge between them. Data was collected from meetings between these agents, and a Content Analysis is carried out. There is an understanding of the field as a microcosm and of the university as a micro-organization or subfield, around areas of knowledge, relating to other fields in a relatively permeable way. Part of these ideas are present in the work of Freitas, Oliveira and Carvalho (2005), in which the relationship of proximity and distance in the inter-field space (school field and scientific field) is more explicit, as a configuration between agents and field is 
presented, showing for example that there may be an approximation related to teaching experience and a distance in terms of research between the university teacher and the school teacher. Thus, there is an emphasis on understanding the field as a social space that allows the analysis of distances and proximity between agents from different fields. The authors recognize that Bourdieu, in Practical Reason, considers the subject's position in relation to the field itself, but intend to explore these "inter-field" positions; there is still a bet on the possibility of articulation starting from the idea that the novices produce changes in the field (Freitas et al., 2005).

A central issue in the study of the concept of field concerns the general and invariable laws of these subspaces of social space, so that it is not any area of knowledge, profession or institution that can be considered an autonomous field. Among the various concepts developed by Bourdieu to construct the theory of fields, we discuss in this article mainly the habitus of agents, the composition and distribution of capital, the structure and relationship of forces, the nomos, the doxa, the belief and the dispute, the boundaries and autonomy of the field and the strategies of the game ${ }^{1}$. In the next section, we discuss these points in dialogue with the analyzed works.

\section{General and invariable laws of fields}

A field is a structured space of positions disputed by agents and institutions. Examining this definition, we can draw an analogy — as Bourdieu does, and think of the field as a game in which there is a common dispute, a set of specific rules and limits that need to be followed, players more or less skilled and interested in the competition, partners to play with and others to oppose, styles and appropriate ways to play; there must also be cards or trump cards distributed and manipulated among the players, strategies to be used to occupy one or another position, paths to be conquered and possible movements to be performed in the space of the game.

In this space there are objects of dispute and irreducible interests, perceived only by those who are trained or interested in entering this field. For example, what is at stake in the scientific field is the power to impose a conception of science that sets problems, methods and theories considered legitimate; and to establish a scientific order (Bourdieu, 1983a). Thus, it is of utmost importance that the rules that are being played in that social subspace be established as a starting point for the description of field, under penalty of relativizing the concept to the point of reducing its analytical power. For example, Feres' (2010) doctoral thesis aimed to investigate the area of science education, specifically postgraduate programs, understanding origin, constitution and institutionalization. Based on the principle that postgraduate studies in science education constitute a scientific field, the author sought to mobilize, under the Bourdieusian perspective, the

1 Other concepts such as position, dispute, legitimacy, specific fields (power, economic, religious, scientific, educational, among others) and homology, also present in the field theory, are only mentioned without detail, since it is not our goal to describe the whole theory, and the space of the article does not allow explaining all the terms and concepts presented. To clear out any possible doubts regarding Bourdieusian concepts, we suggest consulting Bourdieu's Vocabulary, organized by Catani, Nogueira, Hey and Medeiros (2017). 
habitus of this field, its intellectual capital and the strategies that characterize agents' disputes and interests. Feres (2010) presents a thorough historical reconstruction of the area (occupying more than 100 pages of the thesis), however, the discussions about the specific properties that justify this space as a field do not have the same level of detail. When synthesizing graduate studies as a field, Feres (2010, p. 208) states that it is:

a scientific field with its own object and objectives, given a dominating contribution of postgraduate programs for its constitution and institutionalization in the country; that in this constituted field the existence of a habitus with its own dimensions and characteristics is visible, although similar to other fields and their multidisciplinary relations; and, that it can also be inferred about the presence of a cultural or scientific capital that demonstrates a trajectory and tradition constituted through specific strategies and delimited by an ambience that presents factors of influence of a certain nature.

That is, instead of showing the mechanisms that structure the struggles of the field and unveiling its internal logic, the author chooses to reproduce the Bourdieusian concepts in a more descriptive, generic and less relational analysis.

Along the same lines, Pereira (1999) developed a study on the prestige of teacher education programs from a reconstruction of the historical process behind the creation of the Biological Sciences course at UFMG, considered by the author to be a specific field. Similar to Feres (2010), Pereira (1999) presents an in-depth analysis of the roots of this course, mobilizing some fundamental concepts such as habitus and capital. However, perhaps due to the limited space available, the author does not invest in articulating and deepening the concepts that make it possible to interpret, and not just announce, the course in question as an autonomous and well-established field. Freitas and Fernandez (2015) also understand the field as a social space with a particular structure and specific objectives, which works relatively autonomously. They point out the existence of a professional field within the university field, in which the university teaching subfield is. They also state that a "the more the products are consumed in a field, so much more autonomous the field is, indicating there must be a producer and a consumer pole within the field itself" (Freitas \& Fernandes, 2015, p. 260). In this sense, they claimed that teaching is consumed by undergraduates. The research question mentions the "educational field", but its relationship is not clear, which appears only in the introductory sections with the other fields mentioned, such as happens with the university teaching subfield.

We realized that these three studies share the fact that they consider the existence of the field as a priori data, that is, with no explanation of the reference nor identification of the general laws and specific field properties defined by Bourdieu. In other words, all the authors started from the principle that they study a field. We understand that Bourdieu has not distinguished clearly between what is or not a field, as well as that some spaces function as fields or subfields depending on the relationships that are being studied. Thus, at times haute couture is a field (Bourdieu, 2002a), while in others it 
is a subfield of the field of intellectual production (Bourdieu, 1968). We understand that these variations do not represent inconsistencies, but open the possibility of several relational approaches in the study of fields. Thus, when locating a field or subfield in relation to adjacent fields, Freitas and Fernandez (2015), for example, show this effort to delimit the field.

However, we defend that there is a fundamental dimension of the concept that seems to be absent in some studies that define the field only as a structured space of positions, that is, they disregard that these positions are only structured according to the possession of a specific volume of specific capital. Thus, it is not the positions that matter, but the capital, which requires the identification of a specific capital clearly desired by all agents in the field. This is also done by Freitas and Fernandes (2015) when investigating the kind of capital for university teaching. However, the concept of capital requires the identification of certain recognition and profitability, that is, it is only capital if it can be exchanged for benefits or advantageous profits. The set of works in the area discussed in this article indicate specific fields and capitals, but do not explain this conceptual dimension of capital. In addition, understanding that the notion of field arises to overcome the false dichotomy between internalism and externalism and recognizing that the existence of limits and autonomy is what defines the existence of the field, we realize that the specific capital of a field must be minimally recognized outside the limits of the field. This is clear when Bourdieu (1983a) indicates that the dispute in the scientific field is for scientific truth and that this capital and its owners are publicly recognized outside the internal limits of the field. With this interpretation and insertion of the "field of higher education" into the "university field", it is hard to recognize the legitimacy and value of the capital behind university teaching, indicated by Freitas and Fernandez (2015) as the ability to give good classes and the ownership of experience, since this is not recognized internally at the university and much less externally. Thus, although this finding is extremely unfavorable for all of us involved in Science Education, it seems to us that the concept of the field does not contribute to understanding these disputes, which probably do not refer to a field.

In addition, it is important to highlight that, according to our interpretation, based on the works of Bourdieu (2007b, 2008), we are all inserted in the linguistic field and in the field of social classes. Thus, we are influenced by this dispute for capital and more legitimate positions in which there is a clear recognition and profitability of capital considered more legitimate in these fields. Therefore, we understand that it is necessary to make an effort to distinguish between disputes specific to a field from general disputes of social classes, to which we are always subject. Confirming our understanding, Lahire (2002) states that some social spaces, such as the family, are not fields, since occupied positions cannot be exchanged, and we can, add according to our argument, that what is in dispute is neither profitable nor recognized outside family's internal limits.

Moving towards internal and constituent elements of social subspaces, for a field to work, there must be people (agents) and institutions willing to play this game. Agents 
are endowed with a habitus of their own that implies knowing and recognizing the laws of this field (Bourdieu, 1989a). Being the product of the internalization of the game structure, this system of thoughts, perceptions and appraisals, which is the habitus, determines the skills of the players, the way they can play and the positions they can occupy. In classical physics, the interaction between particles that are not in contact was a very strange fact to 18th century physicists. Thus, to explain the forces of action at a distance, a mathematical resource was developed, which was called field (Griffiths, 2005; Jackson, 2007; Jammer, 1993; Nussenzveig, 2015). Under those circumstances, this mathematical entity would be spread over the physical space and would justify the interaction of the particles even at great distances. For that effect, the field is always what mediates the interaction between charged particles in physical space. In the case of electrostatics, each particle individually produces an electric field around its surroundings, which is more or less intense depending on the charge on the body and that decreases as we move away from the particle. In other words, each charged particle produces its own field wherever it is inserted. The use of the field to analyze interactions between bodies at a distance is also present in other branches of physics, such as magnetism and gravitation. Considering the relational nature of the Bourdieusian theory of fields (Klüger, 2018), it makes no sense to analyze the participation of agents in isolation in the social space. It is essential to understand how an agent is positioned in this space always in relation to the position of other agents that are part of the social space.

Conceição's master's dissertation (2012) aimed to evaluate public policies aimed at Scientific Initiation (SI) at a state university, based on the Bourdieusian notion of scientific field. The author presents a historical reconstruction of SI in Brazil, identifying the main agents, institutions and contexts that enabled the emergence of Brazilian scientific research. Then, the paper evaluates the implementation of Junior SI programs in a university, analyzing competences, time, resources and strategies that the institution demands of the participants. In other words, it investigates constitutive aspects of the scientific habitus demanded by the university field. However, it is based on the subjects' discourse to analyze the habitus, considering the SI student as an agent of the field. Conceição (2012) understood the constitution of the habitus as an immediate event, and not as a structuring structure that forms thought schemes. For the author, living together in research laboratories for a while is enough to form a habitus appropriate to the field in the high school student, capable of constituting him as an agent who will compete in this field. Perelli and Gianotto (2005) conducted a similar analysis, investigating the perceptions of university professors when choosing SI students. The authors assumed that simply being in the laboratory and in research groups for a brief period of time is capable of forming in students a scientific habitus that reflects normal science. For the authors, since SI students are considered as agents of the field, the science game begins to be played way before they enter university, when they develop skills, such as autonomy and decision-making, which are required by the scientific field.

In his doctoral thesis, Dorvillé (2010) analyzes the tensions and conflicts that 
emerge from the movement of the same agent between fields, namely, from the religious field to the scientific field. The identity processes of evangelical students in a Biology course and their relationship with academic contents were studied (Dorvillé, 2010). The author assumes that it is fundamental that science education promotes changes in students' worldviews through the promotion of dissonant situations with the original habitus of these students. In our interpretation, Dorvillé (2010) extrapolates the Bourdieusian notions when considering evangelical students as agents in the religious field, as well as Conceição (2012) when considering high school students as agents in the scientific field. Freitas and Fernandez (2015) also understand that students are components of the configuration of the field and not "submissive beings". In another moment, they state that students are agents in the field of university teaching, as they would allocate capital to teachers known for the quality of their classes. We do not reject or endorse these claims, but further theoretical and empirical investment by the authors is rather necessary to support these theses. In the definition of field properties, Bourdieu (1983c) clearly indicates that the agents in the field are only those who hold the specific habitus and are in a position to dispute the specific capital of the field, in addition to defining two types of strategies employed by these agents in in relation to specific capital: conservation or maintenance. Lahire (2002) states that not everyone involved or close to the field is an agent, exemplifying this understanding with the situation of a ball boy who does not belong to the sports field in a tennis match. Thus, we understand that only the agent is an effective participant in the dispute, not one who just watches. Therefore, we have difficulty in imagining that the fact of attending a church or a university enables these agents to dispute the specific capital of these fields.

Taking care not to position individuals deductively in specific fields and recognizing our belonging to the linguistic field, Martins et al. (2005) analyze the speech of science teachers in workshops for teacher training. The authors analyzed the linguistic habitus of the place of origin of the discourses, identifying a crossing between scientific and pedagogical fields. Instead of simply assuming that teachers' habitus is that of the scientific field and considering them a participant in this field, the authors show that this individual's discourse is close to a linguistic habitus that is typical of the scientific field, often incorporated in the university academic environment. We reiterate that we all belong to the linguistic field, as it does not refer to the field of linguistic production, which is probably located in academic, scientific or university fields, but rather to a field of usage of language, as explained by Bourdieu (2008).

The strength of an agent and their position in the field depend on their capital assets. Capitals can be understood as the assets of the game, the powers that are distributed, exchanged and accumulated. In each field there is a specific capital accumulated over the previous struggles and distributed unevenly among the agents and institutions in that field. This distribution sets up the structure, that is, it establishes a state of power relations that exerts pressure on all those engaged in the field. This means that "the weight associated with an agent depends on all other points and on the relations between 
them, that is, on the entire space understood as a relational constellation" (Bourdieu 2005, p. 24). A look at classical physics helps us to visualize these definitions. A basic interpretation in electrostatics indicates that the electrical charge of an electrified body is dependent on the number of excess or missing electrons in that body. That is, the more or less electrons a body has in relation to the neutral state, the greater the magnitude of its electrical charge and, consequently, the greater the interaction with the other agents present in the physical space. For Bourdieu (1983c), Agents are distributed hierarchically within the social space based on their social properties, with groupings formed from similarities between these properties. In other words, among a group of agents, the more common a social property is, the greater the chance of these agents being positioned closely in the social space. For example, people with high cultural capital tend to group together in the social space, as they share a series of tastes and dispositions that are not characteristic of agents of low cultural capital, which, on the other hand, will also be more or less grouped in the social space, but by sharing other properties (Bourdieu, 1983c). In effect, the more frequent among agents the property of a specific agent is, the greater the chance that these agents are cohesively grouped. Therefore, the recurrence of the social property of an agent within the group increases the chance of grouping, that is, this frequency has the characteristic of bringing agents together, which is a characteristic of Coulomb's law of electrical force ${ }^{2}$.

\section{Some specific properties of fields}

The interests of the field dictate the rules of the game, and in each field a legitimate point of view on the field is to be imposed, a fundamental law, a principle of vision and division. Namely, it is a nomos that defines an artistic field (or another) as such, as the place of art as art, which determines true artists (Bourdieu, 1996). The nomos gives the right of entry to the field and defines the limits of the groups formed and the conditions for participation: only those who are gifted from the point of view of the field enter, that is, those who know the rules and are willing to play them.

Freitas $(2008$, p. 28$)$ gave prominence to this property to analyze the field, as "this leads us to the question of the doxa assumed by the subjects/agents", understood by the author as the maintenance of "a project of society that is given", in which "any transformation process is assumed to be harmful, since in the entire transformation process there is a loss of capital, as it questions the logic of the system". The author understands that any attempt to change in this system makes the agent feel marginalized. This understanding of doxa and interest disregards that the field is defined by the very dispute of positions and capitals that reveal the doxa, for example in the dispute between the old and the new that occurs in the field of haute couture (Bourdieu, 2002a). Freitas and Fernandez (2015) highlight this dispute in the field of university teaching,

2 In Physics, attraction between particles occurs with charges of opposite sign, and repulsion with those with same sign. As Bourdieu (Klüger, 2018), we also emphasize the cases of attraction between agents due to proximities in the fundamentals of the Analysis of Correspondence. 
pointing out that the capital from experience is something that participates in the dispute for power in the field, as happens with the decision to not support a budding colleague. Under this circumstance, newcomers in the field accumulate cultural and symbolic capital until they are able to question the rules of the game in a dominantsubmissive relationship in which the more experienced ones exercise over the younger ones; "obtaining prestige from students is a means of increasing symbolic capital and strengthening power relationships with other agents in the field" [...] "if they 'weaken' in the way of transmitting knowledge he can be considered a teacher less efficient and have a lower position in the field" (Freitas \& Fernandez, 2015, pp. 266-267). In conclusion, the authors reiterate the "own characteristics, tensions and difficulties of the microfield of teaching work in Higher Education at the beginning of their careers" (Freitas \& Fernandez, 2015, p. 270), indicating relations of superiority of novice teachers in relation to students and domination of experienced teachers in relation to novices.

This set of discussions presented so far seems to demonstrate the strong relationship that an agent establishes with the field, leading them to develop, through a long and recurring process, their own habitus along with the original habitus from the field of social classes. Therefore, the idea presented by some authors (Conceição, 2012; Freitas, 2008; Perrelli, 1996; Perelli \& Gianotto, 2005) are, to say the least, intriguing, as agents can be in several fields at the same time, that it would be possible for the agent to recognize their position in the field and, when they become aware of that position, change their habitus or their strategy, almost as if the agents had the ability to move easily between fields, as an idea of "flex field". Perrelli (1996) compares habitus to the notion of epistemological obstacle. And although this obstacle consistently points to the character of apparent inheritability and spontaneity, it bets on the possibility of overcoming or changing the habitus. Another comparison of the author is that the field can be presented as a zone of the conceptual profiles, when perceiving writers' inferior position in the field of cultural industry due to their low cultural and economic capital, suggesting that the authors should invest in their cultural capital in a way to subvert those positions. It is important to highlight that in the only work in which he analyzes transformation processes involving the fact that an Algerian tribal society adhered to a capitalist mode of production, Bourdieu (1979) writes much more on hysteresis (the individual's tendency to maintain their original habitus even though it is inadequate for the new situation) rather than on changing the habitus.

As in the research by Freitas and Fernandez (2015), other authors are dedicated to defining a specific capital for the field by analyzing and discussing implications in the positions of agents (Condenanza, 2012; Perrelli \& Gianotto, 2005; Ribeiro, 2008; Genovese, 2008). On understanding environmental education as a field, Condenanza (2012) analyzed in her doctoral thesis the dispute for a symbolic capital specific to that field, related to the possibility of pushing, through action and theory, several political projects that serve the purposes of environmental education. Perelli and Gianotto (2005), when investigating SI students also assume the existence of specific capitals from the 
scientific field, given by the title and publications in partnership with the research advisor and the interest in acquiring authority. For Conceição (2012), SI students accumulate symbolic and cultural capital, as agents of the scientific field, who would help them to enter higher education, through the entrance exam, illustrating the exchange character of capital, albeit in a very utilitarian way. Ribeiro (2008), investigated in his doctoral thesis the political and epistemological clashes underlying the implementation of chemistry education programs at evening, capturing the symbolic negotiations and the prevalence of interests of hegemonic groups associated with the creation and organization of this course.

One of the most in-depth studies on the field, which builds the school field in relation to the educational field and defines specific capitals, is the doctoral dissertation by Genovese (2008). The school field refers to the specific school that the author studied, and the educational field is broader, associated with the educational system. Homo Magister is how the author names the teacher in the educational field, whose knowledge and recognition are the object of his thesis. To configure this field, he analyzes the city's power field and the position of a school in relation to others in the city, defining it as dominant within a educational field. According to the author, the educational field was briefly mentioned by Bourdieu (in Practical Reason and In Other Words), being defined according to the following arguments: 1) the existence of a game between schools and their ability to resist changes; 2) schools have already created educational subjects and materials (i.e., sciences and geography) in an independent manner; 3) schools and teaching have their own history. As an analysis methodology, the author indicates the following sequence: configuring the field of power, identifying the structure of objective relations between schools and identifying the agents' systems of disposition and habitus. He defines teaching capital as the sum of educational-cultural capital and social capital: the first is available in three forms (hierarchy of subjects, direction of the school game and possession of resources) and the second is the ability to maintain interpersonal relations of knowledge and recognition. The educational field "is a relatively autonomous field of forces endowed with a structuring and structured structure, due to distribution and hierarchization of schools and teachers" (Genovese, 2008, p. 171), breaking with internalist and externalist views. In a work for ENPEC (Portuguese acronym for National Meeting for Research on Science Education), Genovese (2013) analyzes the interaction between the educational and the university fields. The author used this term, fields, instead of the term university-school relationship, considering that these spaces are "structured and structuring", pointing to competitive and hierarchical relationships between agents. He considers that science teaching is an academic subfield and that there are other fields such as the educational scientific field, the educational scientific field of science education and the scientific field of basic sciences. The author distinguishes between the educational field and the school field, situating the homo magister's habitus and the teaching capital. In this context, social capital "is expressed by the teacher's ability to establish, maintain and mobilize interpersonal relations", and 
studying research groups at university and school constitutes an effort to "intersect the educational and university fields" (Genovese, 2013, p. 3). As in the thesis, the author mobilizes the specific capitals of the educational field: educational-cultural capital and social capital. The author identified several obstacles, such as the school field that accumulates educational-cultural capital and the supervising teacher, who has a habitus that augments social capital. As previously discussed, despite the methodological and empirical details, as well as the deep appropriation of the Bourdieusian theory, we were unable to identify the legitimacy and profitability of the teaching capitals that this author defines.

The field has limits and boundaries that are also objects of conflict and disputed in the game, because defending the boundaries is defending the order established in the field, as well as its names and rules (Bourdieu, 1996, 2005). Boundaries determine the field's autonomy, which is always partial, never reaching total subordination to external demand, nor absolute independence to market requirements (Bourdieu, 1996). The autonomization process is gradual, concomitant with the historical constitution of the field, and proportional to the symbolic capital accumulated over time. A greater degree of autonomy supposes a clearer delimitation of boundaries, a certain independence from external political or economic powers, the constitution of authentic interests subordinated to the field's logic, the ability to define its own principles of legitimacy, the imposition of its nomos, the reinforcement of its laws, the power to allude to the internal history of the field, the improvement in the codification of the rules, the elevation of the right of entry, and a greater reflexivity as a form of self-criticism (Bourdieu, 1989b, 1996). Relating to the concept of electric field, this becomes less intense as we move away from a body. When the distance tends to infinity, the intensity of the electric field tends to zero. In other words, there is a limit in the action of an electric field, which is located at a very distant point (tending to infinity) of the body. This idea of physics brings us to the notion of boundary in Bourdieusian theory. The boundaries of a given social subspace depend on the structure of the dispute relations between the agents of this subspace; they can expand or contract, mitigate or strengthen, always depending on the specific capital distribution among agents within the subspace (Bourdieu, 1983c).

The study of the boundaries and the autonomy of the fields was also subject of research on Science Education. Watanabe, Ribeiro and Kawamura (2013) invested in the study of the interface between scientific dissemination, non-formal spaces and scientific education. From the analysis of the production on these themes in journals of Science Education, the authors concluded that a new autonomous field would be in formation, the field of scientific dissemination and non-formal spaces. The authors themselves recognize the need for more in-depth studies on the position of agents in this field, the dispositions, positions taken, the capital and, in particular, the cultural capital. Contrary to attempts to hybridize religious aspects with scientific content, Dorvillé (2010) defends the importance of strengthening the boundaries of the scientific field. For the author, it is of utmost importance to establish policies that aim to strengthen the boundaries 
of the scientific field and the educational field, removing from science classes both in schools and universities the influences of the religious field. In our view, Dorville's (2010) suggestion shows the idea that the process of establishing fields' borders is a rationally designed process, which depends only on the will of a specific group of agents.

As fields are microcosms of the social cosmos, which is a separate and relatively autonomous private universe, they are subject to external demands, from power, economic and political fields, for example. Likewise, the internal struggles of a field always depend of the homology it maintains with external struggles (Bourdieu, 1996). Although there are structural and functional homologies among all fields, what happens inside a field is not a direct reflection of external demands, but a symbolic expression refracted by the field's own logic (Bourdieu, 1983b).

Ribeiro (2008) presents a historical study of the constitution of chemistry teaching and the clashes between teaching and chemistry. The author made a historical reconstruction of the creation of a chemistry education degree program, showing the debates between the political, scientific and educational fields. In this clash, the educational field is considered to be weakened, devaluing teaching activities, which are considered a strategic condition for the hegemony of the scientific field in competitive struggles, guaranteeing the survival and maintenance of the specific interests of this field in the constitution of the analyzed course (Ribeiro, 2008). In the paper by Condenanza and Cordero (2011), the author discussed interfaces and homologies between fields, as environmental education is impregnated with debates that are specific to scientific, education and environmental management fields, being conceived as a new, intersectional field. Theoretical investigations and elaborations that affect this field emerged from questions originated in a series of disciplines linked to environmental education, such as political economy and environmental engineering. The private sector, as well as international organizations, also affect the definition of the field in terms of tendencies, attitudes and educational trends. Its autonomy stems from the intersection of these different fields and the determinations that arrive from each of them. In summary, for the authors, environmental education can be understood as an emerging field that involves multiple pedagogical discourses and educational practices focused on the environment and nature, plus incipient scientific production (Condenanza \& Cordero, 2011).

In the same line of investigation as that of the interface between fields, the thesis defended by Watanabe (2015) talks primarily about the scientific dissemination produced by scientists. In particular, it deals with the interactions between scientistdisseminators and students in basic education. For the author, scientific dissemination is a boundary that constitutes the link between two worlds, the interface between the scientific field and the educational field. In these terms, scientific dissemination is the space for creation at the border and as an activity coming from the border, capable of absorbing, adapting and reflecting the discourses from both spaces. From this notion, it is possible to understand that scientific dissemination is the product of the clashes between the scientific field and other social fields. The interaction between agents 
from different fields was also investigated by Braga (2004) in her master's dissertation. The author invests in the analysis of the relations among agents/actors involved in the practices of two well-established fields, the artistic field and the scientific field. For Braga (2004), there is a subfield at the intersection between Art and Science, which belongs to the fields of Museum or Science Center, with objectives, struggles and disputes specific to the agents of the fields related to the same theme.

As previously discussed, the studies by Freitas (2008), Freitas et al. (2005) and Genovese (2013) focus on "inter-fields" or intersection spaces between fields, revealing an attempt to fill a gap left by Bourdieu, who has not discussed possible interactions between fields and the position of agents in this context due to the different values of their capitals. Freitas (2008) has identified situations of proximity between agents, as in the case of a teacher from a university with "valid symbolic capital in the academic field" (p. 58); also identified situations of recognition of power structures as well as what was at stake in disputes between agents; analyzed the situations of legitimacy and hierarchy, understood as recognition and analyzed as "recognized capital in the educational and academic segments" (p. 83); and assessed the proximity and distance between agents in the field. The text presents several "paths" to bring the university teacher and the school together, in a way to soften the hierarchy between them and taking advantage of the "inter-field" space that was created.

Another concept for understanding field theory is the struggle between antagonists: the dominated, who seeks right of entry to the field by forcing it, and the dominant, who defends monopoly and attempts to mitigate competition (Bourdieu, 1989a). Like any game, the agents use strategies to modify or maintain their position in the structure of the field, aiming at more favorable positions. The strategies can be of conservation or subversion, those that hold more specific capital tend to employ conservative strategies (orthodoxy), while those that hold less capital, to subversive strategies (heresy, heterodoxy) of the structure and its positions (Bourdieu, 1983c). The strategies stem from the unconscious relationship between habitus and the field (Bourdieu, 1989a).

In a state of doxa, all people engaged in the field have fundamental interests in common, linked to the fundamental axiom of the field. There is a tacitly accepted agreement on what deserves to be disputed among those who dispute the field. When participating in this fight, the game is reproduced and the belief that it exists and is worth playing is produced, the belief in the game is the pedestal on which the entire game stands (Bourdieu, 1989a). The agent must play and not refuse it, because to contest the rules, to refuse the game's nomos is to put the game itself in check and the belief that underlies it, for Bourdieu (1996, p. 196) this is the "the only unforgivable transgression".

"Fighting the good fight" is what keeps this structure unified, it is the game itself that is being played. The field is not formed by a set of individual agents linked by simple interaction or cooperation. It is, in fact, a network of objective relations between positions that form a structure, a space of positions to be taken where each position 
is objectively defined by its relation with other positions. All positions depend on the current and potential situation in the structure, given by the unequal distribution of capital (Bourdieu, 1996).

In this game there are either possible and unthinkable plays, as the players' positions depend on position-takings from among the possible ones. As ruled by the categories of perception of habitus, identifiable as objective potentialities, things 'to be done,' 'movements' to launch, reviews to create, adversaries to combat, established position-takings to be 'overtaken' and so forth. (Bourdieu, 1996). The field is this universe "where to exist is to be different, meaning to occupy a distinct and distinctive position" (Bourdieu, 1996, p. 271). In addition, positions in the field are constructed according to the structure of the field itself, and are homologous to the positions that agents occupy in social and power fields, for instance. As discussed, the closer two electrically charged bodies are in physical space, the greater is the force on them. In Bourdieusian terms, the attraction between two agents will be greater the more similar they are in relation to social aspects (Klüger, 2018). Based on this idea, we understand that the distance between agents in social space and the distance between charged particles in physical space have very similar meanings, since they imply a greater interaction force. This can be corroborated from the concept of distance present in Multiple Correspondence Analysis (MCA), a statistical tool widely used by Bourdieu in his research. In this statistical technique, points are positioned in space based on differences and similarities indicated by categorical data (Greenacre, 2017). These points can be agents, institutions or nations. In the case of placing agents based on categorical data referring to social characteristics, the distance between two agents indicates a greater homogeneity of their social properties (Klüger, 2018). Thus, when two individuals have the same social property (or mark the same category in a question of a certain survey), the distance between them is strictly zero, indicating a maximum possible "attraction". Likewise, according to Coulomb's law, if the distance tends to zero, the force of interaction between agents will tend to infinity. Bourdieu used MCA to a great extent in his investigations, as it can provide representations of social spaces according on the data used (Klüger, 2018; Le Roux \& Rouanet, 2010). This fact reinforces our proposition that the distance between electrically charged particles in physical space can match the concept of distance between agents in social space.

Finally, each act of the game contains the history of the game, which marks the production of that field and the life of the producer (player). It is impossible to understand the product of a field and its value without knowing the history of the field in which it was produced (Bourdieu, 1989a). The history of the field is portrayed in different works (Conceição, 2008; Condenanza 2012; Condenanza \& Cordero 2011; Feres, 2010; Ribeiro, 2008). In general, the authors present a kind of sociogenesis of the field, reconstructing origins, identifying agents, disputes and interfaces with other fields. However, in these studies, the historical analysis generally appears as an introductory chapter, to situate the object, in which a few or no concept of field theory is mobilized, 
and in a more descriptive instead of a non-relational way. The historical sociogenesis of the field is one of the procedures for analyzing a field (Bourdieu, 1996), so we understand that this would be a fundamental step for studies that seek to characterize a field, and not just as an introductory topic.

In addition to the invariant laws of each field, we highlight some specific characteristics to illustrate the mobilization of this concept. In the field of haute couture, Bourdieu (2002a) highlights that the dispute between dominant and dominated usually refers to the old and the new, both in style and in the stylist's consuming public, in which innovation clashes with tradition. Moreover, in this field, there is the phenomenon of transubstantiation, in which a name is transposed, in the form of a trademark, to an object or an agent (disciple of a given maison), thus transferring a part of symbolic capital. In the legal field, Bourdieu (1989c) highlights the role of language and elitization in the construction of this field's relative autonomy, which, as contradictory as it sounds, coexists with a strong dependence or external influence in relation to others (i. e., power, economic, etc.). Bourdieu (1996) developed his most complete analysis of this concept in relation to the artistic field, highlighting its sociogenesis and the relations between producer and consumer in the configuration of disputes and positions of agents. In the economic field, Bourdieu (2005) highlighted the role of brutal sanctions, associated with profit maximization, which contrast with the symbolic sanctions present in most other fields. In the intellectual field, the originality or genius of the creator emerges as an important element in the configuration of this field (Bourdieu, 2004d). In addition, both intellectual and scientific fields (Bourdieu, 1983a, 2004a, 2004b) show two specific and competing capitals, namely, the institutional (temporal) scientific capital, characteristic of trajectories on the occupation of political-scientific positions, and pure (specific) scientific capital, owned by scientists with high symbolic capital resulting from their production of scientific knowledge.

Researchers in Science Education have shown solid initiative in creating new fields to interpret their objects of study. Feres (2010) proposed that Science Education is a scientific field represented by postgraduate studies. Condenanza (2012) recognized environmental education as a field. Watanabe, Ribeiro and Kawamura (2013) established the understanding that there is a field of scientific dissemination/non-formal spaces in the interface with science education. According to the authors, this field is a subfield of the field of scientific education, agreeing with Feres' proposal (2010). Freitas and Fernandez (2015) create the field of teaching in higher education, and Genovese (2008, 2013) and Freitas (2008) start their research from the premise that there is a educational field or a school field. As previously discussed, we understand that outlining a field is a vague subject in the Bourdieusian framework, but we defend the criterion of recognition and profitability of specific capital not only inside, but also outside the field as a reference that makes it difficult to understand these cases as fields.

Understanding Bourdieu's scientific work requires applying a way of thinking in practice. This important sociologist developed a praxeological method of analysis based 
on empiricism and a scientific theory. For him, "scientific works are similar to music that was made not to be more or less passively listened to, or even performed, but to provide principles of composition" (Bourdieu, 1989a, p. 63). The concept of field should be used as such, as an active appropriation of the scientific way of thinking.

In this perspective, thinking in methodological terms, Bourdieu (1996) proposes that the study of any field must operate by three basic procedures intrinsically linked: i) the analysis of the position of the field within the field of power and its evolution over time; ii) the analysis of the internal structure of the field, that is, the structure of the objective relations between the positions occupied by the agents or groups in competition; iii) the analysis of the genesis of the habitus of the occupants of these positions. In The Rules of Art: Genesis and Structure of the Literary Field (1996), the sociologist traced the autonomization process of the literary field through the historical sociogenesis of that field, operating mainly according to the first two procedures listed above. The third procedure is further investigated in Homo Academicus, in which Bourdieu (2017) analyzes habitus and positions occupied in the French university field of the 1960s using the prosopographic method and statistical analysis, such as the MCA.

When we turn to the texts on Science Education, we can see that, in some cases, the authors present Bourdieusian ideas, but do not mobilize them to think of the object. In the cases discussed above, in which the authors seem to define the existence of the field a priori, we miss a larger empirical basis, mainly based on quantitative data or in the stages of field research proposed by Bourdieu (1996): relations with the field of power, the prosopography of agents and the sociogenesis of the field. On the other hand, we recognize that this is a very large analytical effort that would probably be unfeasible, even for a doctorate, in the context of research production that we are experiencing, which is completely different from the French context.

As previously highlighted, another methodological inconsistency identified in the area refers to the legitimate concern of our colleagues in solving problems in Science Education. This is a main concern in our field, which justifies and legitimizes the authors' intentions, whereas the choice for the Bourdieusian framework seems to us to be incompatible with this demand. Bourdieu is an author who allows us to understand the social situation in a profound way, but he does not allow us to produce pedagogical orientations, both because he was not a pedagogue and because he was not concerned with prescribing ways out of the discouraging scenarios he built. This is clear in works such as The weight of the world and The disenchantment of the world. Even when he analyzed the education system, in Reproduction in Education, Society and Culture and The Inheritors, his goal was to unveil the role of the school in the reproduction of social inequalities and not to point out ways of transforming this reality. Despite advocating militancy for intellectuals in the final moments of his production and especially in nonacademic texts (Bourdieu, 2002b), this prescription was not a directive in the sense of guiding interventions on society, but of defending an understanding and the ways of disseminating it. In addition, the depth of the diagnoses produced by the Bourdieusian 
analyses points to power relations between social classes, which can only be overcome with profound social changes that do not belong to research in Science Education. Their theoretical premises consider mainly the unconscious aspect of the incorporation of social structures by individuals, therefore, defending a process of awareness and change of habitus, although often desirable, is very unlikely according to Bourdieu's theory (1979). On the other hand, the various examples of studies in the area brought up in this article illustrate this author's potential in providing significant progress in understanding the problems studied by the area. Unfortunately, mobilizing his theory yields negative results, but clarify the dimensions of the challenges we face as researchers in Science Education.

\section{Conclusions and implications}

The main objective of this work was to make the concept of field theoretically clearer. Recognizing the multiplicity of elements involved (habitus, capital, strategy, structure, among others), which effectively hinders appropriation of this concept (Lahire, 2017; Montagner \& Montagner, 2010), we engaged in reading the author's main works that address this theme over the course of a year. Through careful reading of the texts, followed by discussing and synthesizing, we gained a deep understanding of this theory, in addition to the isolated interpretation of concepts, such as habitus and capital. This dive into Bourdieusian theory revealed the innumerable idiosyncrasies around the concept of field, which motivated the elaboration of this text, so as to contribute to the field of Science Education. In parallel, we used some concepts from Physics to introduce the field theory, in particular electromagnetism, in a way to clarify the interpretation of certain aspects. In the same fashion, we dwelt on some studies in Science Education that mobilized the concept (Valadão, 2016), so that we could not only advance the theoretical understanding while sticking to the area but also illustrate the possible and effective articulations.

We started from the relation between the concept of field, social space and physical space. We showed that the social space, studied by Bourdieu, is based on the contemporary understanding of physical space, in which the spatial dimensions are intertwined with the temporal dimension. We then proceeded to the presentation of general and invariable laws of the fields and concluded with the details of their specific properties, in dialogue, whenever possible, with aspects of Physics and studies in the area of Science Education.

Bourdieu understands that fields are structured subspaces of social space. Its structure comes from disputes between agents (or institutions) for symbolic/material goods, only perceived as objects of interest by those who are part of the field or desire to enter it. As a consequence, it is not any profession or area of knowledge that can be considered an autonomous field. There are general and invariable laws, as well as specific properties of the fields that helps better understand these spaces. We discussed the need to invest in the recognition of objects that are in dispute and the interests of agents who 
are part of or who intend to be part of the field. We noticed that studies on Science Education tend to analyze fields that are adequately defined only as "structured spaces of positions". However, researchers do not invest in tracing the responsible factor for structuring positions in the social space: the volume of specific capital held and disputed by agents. Furthermore, we realize that specific capital needs to be recognized outside the borders of the field. We emphasize that the understanding of what is or is not a field is not clear in the Bourdieusian work, and we note that some spaces are interpreted either as a field or as a subfield, depending on the relations that are being analyzed. In addition, our reading of the works allows us to consider that we are all inserted in the linguistic field and in the field of social classes, disputing more profitable capital and more legitimate positions in these fields. Thus, it is necessary to distinguish between disputes inherent to a specific field and those general to social classes, for example.

We followed the analysis by discussing the characteristics of people or institutions that can be considered as agents of the field. These agents are endowed with a habitus that implies knowing and recognizing the laws of this field and defines the positions that they may occupy (Bourdieu, 1989a). Classical physics helps us to understand this idea with the electrostatic field. Charged particles themselves are responsible for generating the field in which they are inserted, and their interaction with other charged particles configures the field itself. In this sense, not everyone is an agent of the field under analysis, just as neutral particles do not contribute to the configuration of the electrostatic field. In the area of Science Education, we note that some studies put too much into perspective the criterion of entry into the field, contradicting, in our interpretation, the rigor of the Bourdieusian theory in stipulating who is in and out of the field.

The interpretation that an agent's force and position in the field depend on capital assets is another key element in Bourdieusian theory. In classical physics, we observed a similar phenomenon in the study of electrostatics. It is an intrinsic property of particles, the electric charge, that defines how much this particle will be able to attract (or repel) another. In analogy with the social space, the more frequent an agent's social property is in comparison with other agents in the field, the greater their aggregating capacity, that is, the greater their force within this space. In the works in the area of Science Education, we identified a set of authors who invested in defining a specific capital for the field and its implications in the positions of agents (Condenanza, 2012; Freitas \& Fernandez, 2015; Genovese, 2008; Perrelli \& Gianotto, 2005; Ribeiro, 2008).

Regarding the limits and boundaries of fields, which are also objects of conflict and dispute within them, we reinforce that defending the borders is defending the dispute established in the field, its nomos and rules. We show that, in Physics, studying the electric field reveals that intensity decreases with distance, so when distance tends to infinity, the intensity of the electric field tends to zero. That is to say, as in electrostatics, there is in Bourdieusian theory a limit for the field's performance, its boundaries, which depend on the structure of the dispute relations among the agents of this subspace. Boundaries and autonomy of fields were also subject of research on Science Education 
(Condenanza \& Cordero, 2011; Dorvillé, 2010; Watanabe, 2015; Watanabe et al., 2013). With respect to methodology, Bourdieu shows that studying any field requires operating from three organically related procedures: to analyze the position of the field within the field of power; to look at the structure of the objective relations between the positions occupied by the agents and to analyze the genesis of the habitus of the those in these positions.

In summary, on the selection of texts on Science Education that we have selected to advance in understanding this complex concept, which is the field, we note that there is a lot of a priori definitions of fields, without investing in empirical studies that corroborate previous considerations. We also found that researchers use the Bourdieusian framework to solve problems in Science Education. We know that it is a legitimate concern of the authors, however, this choice seems to us incompatible with this demand, since Bourdieu is an author who helps to deeply understand a static social situation, but his theory does not allow to interpret solutions that transform these realities, mainly if they are not structural changes in society. However, we recognize that an active appropriation of Bourdieu's mode of scientific thinking, contemplating theoretical propositions and methodological recommendations, requires a very large analytical effort, which is difficult to find even in doctoral dissertations.

Despite these challenges of understanding, recognized by the author himself (Bourdieu, 2013), we insist on the potential of this framework to contribute to research in Science Education. The several studies cited in this article illustrate the variety of objects dear to our area that can be interpreted through the Bourdieusian lens, such as school, university, non-formal spaces and science in general. In addition, his Sociology of Science and relational thinking make it possible to overcome the internalist and externalist dichotomy and effectively articulate individuals or groups to social contexts. Finally, by providing a precise picture of the power relations involved in scientific fields and subfields, they allow put science at the service of its own progress, guiding prescriptive position-takings that can guide us in the face of important decisions before regulatory or support bodies.

\section{Acknowledgment}

This research was supported by the Coordination for the Improvement of Higher Education Personnel - Brazil (CAPES) — Financing Code 001.

\section{References}

Bourdieu, P. (1968). Campo intelectual e projeto criador [Intellectual field and creative project]. In J. Pouillon (Org.), Problemas do estruturalismo [Problems of structuralism] (pp. 105-145). Zahar.

Bourdieu, P. (1979). O desencantamento do mundo: estruturas econômicas e estruturas temporais [The disenchantment of the world: economic structures and temporal structures]. Editora Perspectiva. 
Bourdieu, P. (1983a). O campo científico [The scientific field]. In R. Ortiz (Org.), Pierre Bourdieu: Sociologia [Pierre Bourdieu: Sociology], (pp. 122-155). Ed. Ática.

Bourdieu, P. (1983b). Mas quem criou os criadores? [But who created the creators?] In P. Bourdieu, Questões de sociologia [Sociology issues], (pp. 162-172). Ed. Marco Zero.

Bourdieu, P. (1983c). Algumas propriedades dos campos [Some properties of the fields]. In P. Bourdieu, Questões de Sociologia [Sociology Issues], (pp. 89-94). Ed. Marco Zero.

Bourdieu, P. (1989a). A gênese dos conceitos de habitus e de campo [The genesis of the concepts of habitus and field]. In P. Bourdieu, $O$ poder simbólico [The symbolic power] (pp. 59-73). Ed. Difel/Bertrand.

Bourdieu, P. (1989b). A representação política. Elementos para uma teoria do campo político [Political representation. Elements for a field theory political]. In P. Bourdieu, $O$ poder simbólico [The symbolic power] (pp. 163-207). Ed. Difel/Bertrand.

Bourdieu, P. (1989c). A força do direito. Elementos para uma sociologia do campo jurídico [The force of law. Elements for a sociology of the juridic field]. In P. Bourdieu, O poder simbólico [The symbolic power] (pp. 209-254). Ed. Difel/Bertrand.

Bourdieu, P. (1996). As regras da arte: gênese e estrutura do campo literário [The rules of art: genesis and structure of the literary field]. Companhia das Letras.

Bourdieu, P. (2002a). O costureiro e sua grife: uma contribuição para a teoria da magia [The seamstress and his brand: a contribution to the theory of magic]. In P. Bourdieu, $A$ Produção da crença: contribuição para uma teoria dos bens simbólicos [Production of belief: contribution to a theory of symbolic goods] (pp. 113-190). Ed. Zouk.

Bourdieu, P. (2002b). Pour un savoir engagé [For committed knowledge]. Le monde diplomatique. https://www.monde-diplomatique.fr/2002/02/BOURDIEU/8602

Bourdieu, P. (2004a). Os usos sociais da ciência: por uma sociologia clínica do campo científico [The social uses of science: for a clinical sociology of the scientific field]. Editora UNESP.

Bourdieu, P. (2004b). Para uma sociologia da ciência [For a sociology of science]. Edições 70.

Bourdieu, P. (2004c). Programa para uma sociologia do esporte [Program for a sociology of sport]. In P. Bourdieu, Coisas Ditas [In Other Words] (pp. 207-220). Ed. Brasiliense.

Bourdieu, P. (2004d). O campo intelectual: um mundo à parte [The intellectual field: a world apart]. In P. Bourdieu, Coisas Ditas [In Others Words] (pp. 169-180). Ed. Brasiliense.

Bourdieu, P. (2005). O campo econômico [The economic field]. Política e sociedade, 4(6).

Bourdieu, P. (2007a). Gênese e estrutura do campo religioso [Genesis and structure of the religious field]. In P. Bourdieu, A economia das trocas simbólicas [The economy symbolic exchanges] (pp. 27-78). Ed. Perspectiva. 
Bourdieu, P. (2007b). A distinção: crítica social do julgamento [The distinction: social criticism of the judgment]. Edusp; Zouk.

Bourdieu, P. (2008). A economia das trocas linguísticas: o que falar quer dizer [The economics of language exchanges: what to say means]. 2.ed. EDUSP.

Bourdieu, P. (2013). Sèminaires sur le concept de champ [Seminars on the field concept], 1972-1975. Actes de la recherche en Sciences Sociales, 200, 4-37.

Braga, M. do R. A. (2004). Relações entre Arte e Ciência em Centros e Museus de Ciências [Relations between Art and Science in Science Centers and Museums]. (Dissertação de mestrado em História das Ciências da Saúde). Casa de Oswaldo Cruz - FIOCRUZ, Rio de Janeiro.

Conceição, A. J. (2012). Contribuições do programa de iniciação científica júnior na Universidade Estadual de Londrina (UEL): a formação de um habitus adequado ao campo científico [Contributions of the junior scientific initiation program in Londrina State University (UEL): the formation of a habitus suitable for the scientific field]. (Dissertação de Mestrado em Políticas Públicas). Universidade Estadual de Maringá, Maringá.

Condenanza, L. M. (2012). Ley Federal de Educación e Ley de Educación Nacional: Un análisis desde la Educación Ambiental [Federal Education Law and National Education Law: An analysis from Environmental Education]. (Tese Licenciatura em Ciências da educação). Universidad Nacional de La Plata, Facultad de Humanidades y Ciencias de la Educación, Departamento de Ciencias de la Educación, La Plata, Argentina.

Condenanza, L., \& Cordero, S. (2011). La educación ambiental desde la teoria de los campos [Environmental education from the field theory]. In Encontro Nacional de Pesquisa em Educação em Ciências. Campinas, SP.

Dorvillé, L. F. M. (2010). Religião, escola e ciência: conflitos e tensões nas visões de mundo de alunos de uma licenciatura em ciências biológicas. (Tese de doutorado em Educação). Faculdade de Educação, Universidade Federal Fluminense, Rio de Janeiro.

dos Reis, U. V., \& Reis, J. C. (2016). (2016). Os conceitos de espaço e de tempo como protagonistas no ensino de Física: um relato sobre uma sequência didática com abordagem histórico-filosófica [The concepts of space and time as protagonists in the teaching of Physics]. Caderno Brasileiro de Ensino de Física, 33(3), 744-778.

Feres, G. G. (2010). A pós-graduação em Ensino de Ciências no Brasil: uma leitura a partir da Teoria de Bourdieu [Graduate studies in Science Education in Brazil]. (Tese de Doutorado em Educação para a Ciência). Faculdade de Ciências, Universidade Estadual Paulista, Bauru.

Feres, G. G., \& Nardi, R. (2007). Parâmetros utilizados para caracterização e avaliação da produção acadêmica na área de Educação em Ciências: estudos preliminares [Parameters used to characterize and evaluate academic production in the area of Science Education]. In Encontro Nacional de Pesquisa em Educação em Ciências. Florianópolis, SC. 
Freire, L. I. F., \& Fernandez, C. (2015). O professor universitário novato: tensões, dilemas e aprendizados no início da carreira docente [The novice college professor: tensions, dilemmas and learning in early teaching careers]. Ciência \& Educação, 21(1), 255-272.

Freitas, Z. L. (2008). Um Projeto de Interação Universidade-Escola como Espaço Formativo para a Docência do Professor Universitário [A University-School Interaction Project as a Formative Space for the Teaching of College Professors]. (Doutorado em Educação para a Ciência). Faculdade de Ciências, Universidade Estadual Paulista, Bauru.

Freitas, Z. L., Oliveira, E. R., \& Carvalho, L. M. O. (2005). Formação contínua de professores da universidade: pesquisadores em Ciências [Continuing training of Science college professors]. In Encontro Nacional de Pesquisa em Educação em Ciências. Bauru, SP.

Genovez, L. G. R. (2008). Homo Magister: conhecimento e reconhecimento de uma professora de ciências pelo campo escolar [Homo Magister: knowledge and recognition of a science teacher by the school field]. (Tese de doutorado em Educação para a Ciência). Faculdade de Ciências, Universidade Estadual Paulista, Bauru.

Grenfell, M. (2018). Uma reflexão sobre a teoria do campo (e dentro dela) na prática [Reflecting in/on field theory in practice]. Tempo Social, revista de sociologia da USP, $30(2)$.

Klüger, E. (2018). Análise de correspondências múltiplas: fundamentos, elaboração e Interpretação [Multiple Correspondence Analyses: fundaments, elaboration and interpretation]. Revista Brasileira de Informação Bibliográfica em Ciências Sociais, 86(2), 68-97. https://doi.org/10.17666/bib8604/2018

Lahire, B. (2002). Reprodução ou prolongamentos críticos? [Reproduction or critical continuations?]. Educação \& Sociedade, ano XXIII, 78, abril, 37-55.

Lahire, B. (2017). Campo [Field]. In A. Catani et al. (Orgs.), Vocabulário Bourdieu [Bourdieu Vocabulary] (pp. 64-66). 1 ed. Autêntica Editora, 2017.

Martins, I., Gouveia, G., Jansen, M., Terreri, L., Fernandes, A., \& Assumpção, A. (2005). Textos, sujeitos e discursos: apropriação de textos de Ciências por formadores de professores [Texts, subjects and speeches]. In Encontro Nacional de Pesquisa em Educação em Ciências. Bauru, SP.

Montagner, M. A., \& Montagner, M. I. (2010). A teoria geral dos campos de Pierre Bourdieu: uma leitura [Pierre Bourdieu's general theory of fields: a reader]. Revista Tempus Actas de Saúde Coletiva, 5(2), 255-273.

Mozzer, N. B., \& Justi, R. (2013). A elaboração de analogias como um processo que favorece a expressão de concepções de professores de química [Drawing of Analogies as a Process that Favours the Expression of Chemistry Teachers Conceptions]. Educación Química, 24, 163-173. 
Nussenzveig, H. M. (2015). Curso de física básica: Eletromagnetismo [Basic Physics Course: Electromagnetism]. Editora Blucher, 3.

Pereira, J. E. D. (1999). Aspectos sócio-históricos da formação inicial de professores de Biologia [Socio-historical aspects of the initial training of Biology teachers]. In Encontro Nacional de Pesquisa em Educação em Ciências. Valinhos, SP.

Perrelli, M. A. S. (1996). Transposição didática no campo da indústria cultural: um estudo dos condicionantes dos conteúdos de Ciências nos livros didáticos [Didactic transposition in the field of cultural industry]. (Dissertação de mestrado em Ciências da Educação). Programa de Pós-Graduação em Educação, Universidade Federal de Santa Catarina, Florianópolis.

Perrelli, M. A. S., \& Gianotto, D. E. P. Percepções de professores universitários sobre a iniciação científica: uma análise a partir de Pierre Bourdieu e Thomas Kuhn [Perceptions of college professors about scientific initiation]. In Encontro Nacional de Pesquisa em Educação em Ciências. Bauru, SP.

Porto, C. M., \& Porto, M. M. (2008). Uma visão do espaço na mecânica newtoniana e na teoria da relatividade de Einstein [A space view in newtonian mechanics and Einstein's theory of relativity]. Revista Brasileira de Ensino de Física, 30(1), 1603.1-1603.8. https:// doi.org/10.1590/S1806-11172008000100017

Ribeiro, L. C. S. (2008). A criação da licenciatura noturna em química da UFRJ: embates, retóricas e conciliações [The creation of the night degree in chemistry at UFRJ: clashes, rhetoric and reconciliations]. (Tese de doutorado em Educação: História, Política e Sociedade). Pontifícia Universidade Católica de São Paulo, São Paulo.

Valadão, L. D. (2016). Apropriação da perspectiva teórica de Bourdieu na pesquisa em Educação em Ciências: uma revisão bibliográfica. [Appropriation of Bourdieu's theoretical perspective in research in Science Education] (Dissertação de mestrado em Educação). Faculdade de Educação, Universidade Federal de Juiz de Fora, Juiz de Fora.

Watanabe, G. (2015). A divulgação científica produzida por cientista: contribuições para o capital cultural [Scientific dissemination produced by a scientist: contributions to cultural capital]. (Tese de doutorado em Ensino de Física). Faculdade de Educação, Instituto de Física, Instituto de Química e Instituto de Biociências, Universidade de São Paulo, São Paulo.

Watanabe, G., Ribeiro, R. A., \& Kawamura, M. R. D. (2013). A pesquisa em divulgação científica e espaços não formais de educação como campo [Research in science communication and non-formal spaces of education as a field]. In Encontro Nacional de Pesquisa em Educação em Ciências. Águas de Lindóia, SP. 
Luciana Massi

São Paulo State University (Unesp) School of Humanities and Sciences

Education Department Araraquara, São Paulo, Brazil luciana.massi@unesp.br

Gabriela Agostini

São Paulo State University (Unesp) School of Sciences Post-graduate program in Science Education Bauru, São Paulo, Brazil gabriela.agostini@unesp.br

${ }^{\circledR}$ Matheus Monteiro Nascimento

The Federal University of Rio Grande do Sul Physics Institute, Physics Department Porto Alegre, Rio Grande do Sul, Brazil matheus.monteiro@ufrgs.br

Editor in charge Alessandro Damásio Trani Gomes

\section{Disclosure statement}

No potential conflict of interest was reported by the authors.

Compliance with Ethical Standards

The authors declare this study was conducted following ethical principles. 